\begin{tabular}{|l|l|}
\hline Jarnal Bimbingan dan Konseling Ar-Rahman \\
Volume 5, Nomor 2, Tahun 2019 \\
Tersedia Online: http://ojs.uniska.ac.id/index.php/BKA \\
e-ISSN 2477-6300
\end{tabular}

\title{
STRATEGI GURU BIMBINGAN DAN KONSELING DALAM MENGATASI SISWA YANG TIDAK DISIPLIN DI SMP NEGERI 17 BANJARMASIN
}

\author{
Yohana, Gusti Irhamni, Ainun Heiriyah \\ Program Studi Bimbingan dan Konseling, Fakultas Keguruan dan Ilmu Pendidikan, Universitas Islam \\ Kalimantan Muhammad Arsyad Al Banjari, Banjarmasin \\ yohanasaputra5@gmail.com
}

\begin{abstract}
ABSTRAK
Berbicara mengenai remaja disekolah, masih ada saja siswa yang melanggar aturan tata tertib disekolah, sama halnya di SMP Negeri 17 Banjarmasin, padahal aturan tersebut sudah ada dan juga diketahui oleh para siswa tetapi masih ada yang melanggar salah satunya adalah siswa yang sering datang terlambat dilakukan secara berulang-ulang dengan siswa yang sama adapun keterlambatan tersebut dari faktor dirinya sendiri tanpa ada factor lain. Tujuan penelitian untuk mengetahui stategi yang dipakai guru Bimbingan dan Konseling dalam mengatasi ketidak disiplinan siswa yang sering datang terlambat. Metode yang digunakan dalam penelitian ini adalah kualitatif. Hasil penelitian strategi yang digunakan guru Bimbingan dan Konseling di SMP Negeri 17 Banjarmasin dalam mengatasi siswa yang tidak disiplin dengan memberikan layanan konseling individual dengan teknik modelling. Kedisiplinan sangat perlu ditumbuhkan sejak dini, karena pribadi yang disiplin mampu menjadikan sesorang memiliki kecakapan mengenai cara berpikir yang baik dan juga merupakan suatu proses pembentukan watak serta karakter yang baik.
\end{abstract}

Kata Kunci: Strategi; Guru Bimbingan dan Konseling; Disiplin

\begin{abstract}
Talk about teenagers in school, there are still students who violate the rules of discipline in school, the same as in SMP Negeri 17 Banjarmasin, even though these rules already exist and are also known by students but there are still those who violate one of them is students who often arrive late in the manner repeatedly with the same student as for the delay from the factor itself without any other factor. The purpose of this research is to find out the strategies used by the Guidance and Counseling teacher in overcoming the discipline of students who often come late. The method used in this research is qualitative. The results of the research strategy used by the Guidance and Counseling teacher at SMP Negeri 17 Banjarmasin in dealing with students who are not disciplined by providing individual counseling services with modeling techniques. Discipline really needs to be grown early, because a disciplined person is able to make someone have skills about good thinking and is also a process of forming good character and character.
\end{abstract}

Keywords: Strategy; Guidance and Counseling Teachers; Discipline

Dipublikasikan Oleh :

UPT Publikasi dan Pengelolaan Jurnal

Universitas Islam Kalimantan Muhammad Arsyad Al-Banjari Banjarmasin 
Yohana, Gusti Irhamni, Ainun Heiriyah

Jurnal Bimbingan dan Konseling Ar-Rahman

Volume 5, Nomor 2, Tahun 2019

e-ISSN 2477-6300

\section{PENDAHULUAN}

Pendidikan merupakan kunci utama yang sangat penting bagi kehidupan setiap individu, pendidikan juga dapat memberikan kehidupan yang lebih cerah untuk masa yang akan datang. Pendidikan mempunyai peran bagi kehidupan berbangsa dan bernegara, karena pendidikan itu sendiri dapat menjadi tolak ukur keberhasilan bangsa untuk mencetak generasi-generasi yang berkualitas karena tanpa adanya pendidikan kualitas diri juga akan sangat rendah. Dalam lembaga pendidikan, menjadikan sekolah sebagai lembaga pendidikan formal, maksudnya adalah untuk menyiapkan kondisi, sarana atau prasarana, serta kurikulum yang mengarah kepada pembentukkan setiap individu.

Guru bimbingan dan konseling memiliki banyak strategi dalam meningkatkan kedisiplinan siswa-siswi disekolah, karena guru bimbingan dan konseling sangat berperan dan bertanggung jawab penuh dalam membentuk serta membangun keperibadian siswa-siswi yang disiplin. (Noviaty, Yuliansyah, \& Fauzi 2018, p. 9). bimbingan sebagai salah satu proses pemberian bantuan kepada individu yang dilakukan secara berkesinambungan, supaya individu tersebut dapat memahami dirinya, sehingga dia sanggup mengarahkan dirinya dan bertindak secara wajar, sesuai dengan tuntutan dan keadaan lingkungan sekolah, keluarga, masyarakat, dan kehidupan pada umumnya (Yusuf, 2016, p. 6).

Strategi guru bimbingan dan konseling adalah upaya-upaya untuk membantu siswa-siswi dalam mengatasi masalahnya juga sebagai pelaksana utama yang mengkoordinir semua kegiatan bimbingan dan konseling disekolah tersebut dalam membantu siswasiswi menyelesaikan masalah-masalah yang dihadapinya.

Menurut Prijodarminto, (Sulaiman, 2013, p. 6) kedisiplinan merupakan suatu keadaan yang tercipta serta terbentuk melalui proses dari serangkaian prilaku-perilaku yang menunjukkan nilai-nilai taat, patuh, kesetiaan, teratur, dan tertib. Seseorang yang disiplin bisa dilihat dari sikap dan perbuatan yang dilakukannya, disiplin sama sekali tidak dirasakan sebagai beban, bahkan sebaliknya akan membebani dirinya bilamana ia tidak berbuat sebagaimana lazimnya.

Disiplin ditunjukkan kepada instruksi sistematis yang diberikan kepada peserta didik (disciple) seperti aturan-aturan yang ada disekolah. Kedisiplinan berarti menginstruksikan seseorang untuk mengikuti tatanan tertentu melalui aturan-aturan yang ada (Suhardi, 2017, p. 35). Sejatinya seorang murid atau remaja hanya membutuhkan arahan yang tepat agar nantinya dapat dijadikan pegangan dalam menjalani hidup (Husni, 2017, p. 56).

Tulus mengemukakan kegunaan dan pentingnya disiplin bagi diri siswa, yaitu: 1)
Memberikan dukungan bagi terciptanya perilaku yang tidak meyimpang, 2) Membantu siswa memahami dan menyesuaikan diri dengan tuntutan lingkungan, 3) Menjauhkan siswa melakukan hal-hal yang dilarang sekolah, 4) Mendorong siswa melakukan hal-hal yang baik dan benar. 5) Peserta didik belajar hidup dengan kebiasaan-kebiasaan yang baik, positif dan bermanfaat bagi diri dan lingkungannya (Fiana, Daharnis, \& Mursyid, 2013, p. 27). Hal ini senada juga dikemukakan Maman Rachman, faktor penyebab pelanggaran disiplin disekolah berasal dari luar diri siswa yaitu (1) keluarga yang sibuk dan kurang memperhatikan anak-anaknya, serta banyak problem, dan (2) keluarga yang kurang mendukung penerapan disiplin disekolah (Ilahi, Syahniar, \& Ibrahim, 2013, p. 20)

Fenomena yang ditemui, dari hasil observasi yang dilakukan oleh peneliti saat melaksanakan observasi di SMP Negeri 17 Banjarmasin, menunjukan ada beberapa siswa yang mengalami masalah kedisiplinan. Siswa yang melanggar peraturan sekolah disebabkan karena beberapa faktor diantaranya adalah kurangnya kesadaran siswa dalam mengatur waktu sehingga siswa sering datang terlambat kesekolah, juga kurangnya sikap disiplin siswa yang sering melanggar tata tertib disekolah hal ini terlihat adanya siswa yang tidak memakai atribut sekolah, berkeliaran dikantin saat jam belajar mengajar, tidak mengerjakan PR, rambut siswa lakilaki yang tidak memenuhi standar aturan sekolah, siswa tidak membawa peralatan pembelajaran.

Berdasarkan hasil observasi dan wawancara yang peneliti lakukan bersama 3 orang guru bimbingan dan konseling di SMP Negeri 17 Banjarmasin pada selasa, 2 April 2019. Dalam pembahasan guru bimbingan dan konseling mengatakan bahwa disekolah tersebut memang banyak siswa yang sering datang terlambat kesekolah, walaupun siswa yang terlambat itu berbeda beda setiap harinya, akan tetapi juga ditemui individu yang sama sering terlambat dilihat dari catatan pengawas harian dan data poin sekolah. Biasanya siswa yang datang terlambat diberikan hukuman ringan seperti membersihkan sampah dan tidak diperbolehkan masuk kelas pada jam pertama. Peneliti juga melakukan wawancara pada 2 orang mahasiswa yang pernah praktik disana selama tiga bulan, mereka juga mengatakan bahwa siswa disekolah tersebut banyak yang siswa melanggar peraturan seperti tidak memakai atribut, siswa membolos pergi kepasar, siswa keluar saat jam pelajaran masih berlangsung, siswa membolos saat jam pelajaran, siswa izin ketoilet tapi nongkrong dikantin, dan khususnya siswa yang sering terlambat datang sekolah.

Dalam penelitian (Novianty, Yuliansyah, \& Fauzi 2018) disebutkan bahwa kurangnya kedisiplinan pada siswa ini lumayan terjadi disekolah, siswa yang 
Yohana, Gusti Irhamni, Ainun Heiriyah

Jurnal Bimbingan dan Konseling Ar-Rahman

Volume 5, Nomor 2, Tahun 2019

e-ISSN 2477-6300

terlambat datang kesekolah, berpakaian tidak sesuai aturan, sering tidak masuk sekolah dan hal ini yang sering dikeluhkan oleh guru-guru mata pelajaran dan guru-guru yang lain. Dengan mewawancarai semua guru bimbingan dan konseling yang ada di MAN 1 Banjarmasin, sebagai informan. Metode yang digunakan adalah metode kualitatif Dalam konseling individual ini diharapkan konseli dapat mengubah sikap, keputusan diri sendiri sehingga siswa dapat lebih baik menyesuaikan diri sendiri dan masyarakat sekitarnya.

Sesorang yang baru memasuki masa remaja sangat perlu adanya bimbingan dan kontrol dari orang tua, juga perlu adanya bimbingan oleh guru disekolah. Namun dalam membentuk kedisiplinan anak, yang terpenting adalah bagaimana anak bisa mengendalikan dirinya. Maka siswa yang sering terlambat sekolah itu, merupakan bentuk dari melanggar aturan sekolah. Melihat permasalahan yang ada peneliti ingin mengetahui strategi guru bimbingan dan konseling untuk mengatasi siswa yang sering datang terlambat kesekolah, yang dilaksanakan oleh guru bimbingan dan konseling, diharapkan siswa dapat mematuhi peraturan-peraturan tata tertib sekolah dan dapat menerapkan disiplin disekolah maupun dilingkungan lainnya. Oleh karena itu peneliti tertarik untuk melakukan penelitian dengan judul "Strategi Guru Bimbingan Dan Konseling dalam Mengatasi Siswa yang Tidak Disiplin di SMP Negeri 17 Banjarmasin”.

\section{METODE}

Metode penelitian kualitatif yaitu metode penelitian yang berlandaskan filsafat postpositivisme, digunakan untuk meneliti dalam kondisi obyek yang alamiah, (sebagai lawannya adalah eksperimen) dimana peneliti adalah sebagai instrument kunci, pengambilan sampel sumber data dilakukan secara purposive dan teknik pengumpulan dengan trianggulasi atau gabungan dari keseluruhan data yang didapat, analisis data bersifat induktif/kualitatif. dan hasil penelitian kualitatif lebih menekankan makna dari pada generalisas (Sugiyono, 2016,p. 15).

Penelitian ini bersifat naratif yang menghasilkan data deskriptif berupa ucapan, tulisan, sehingga menghasilkan fakta secara sistematik tentang keadaan obyek sebenarnya, dan lebih menekankan atas dasar atau fakta-fakta yang terjadi di SMP Negeri 17 Banjarmasin. Dalam menentukan subyek penelitian peneliti menggunakan trianggulasi diartikan sebagai teknik pengumpulan data yang bersifat menggabungkan dari berbagai teknik pengumpulan data dan sumber data yang telah ada. Adapun subyek penelitian yang akan dilaksanakan adalah Guru bimbingan dan konseling 3 orang dan Guru wali kelas 1 orang sesuai dengan kelas yang dibina, juga kepada Kepala Sekolah dan pada siswa kelas IX dari 8 kelas akan diambil sebanyak 3 orang siswa yang sering datang terlambat dari kelas 7 dan 8 di SMP Negeri 17 Banjarmasin.

Berdasarkan pengambilan sampel Siswa yang dipilih 3 orang tersebut adalah siswa yang memang sering sekali datang terlambat dari kelas VII hingga kelas VIII. Dalam penggalian data dengan wali kelas yang memang terdapat siswa sering datang terlambat dikelas tersebut sehingga peneliti ingin mengetahui bagaimana kerjasama yang dilakukan guru bimbingan konseling dengan wali kelas. Peneliti juga melakukan wawancara pada guru bimbingan konseling untuk mengetahui bagaimana proses pelaksanaan layanan yang diberikan, kemudian dengan kepala sekolah peneliti ingin mengetahui bagaimana dengan adanya guru bimbingan dan konseling disekolah apakah dapat membuat perubahan untuk siswa dan siswi dalam hal menaati aturan yang ada.

\section{HASIL DAN PEMBAHASAN}

Observasi yang dilakukan oleh peneliti mendatangi sekolah pada tanggal 21 Maret 2019 dari jam 07:30 WITA. Sehingga peneliti menemui permasalahan tersebut, yang menunjukkan ada beberapa siswa yang mengalami masalah kedisiplinan. Siswa yang melanggar peraturan sekolah disebabkan karena beberapa faktor diantaranya adalah kurangnya kesadaran siswa dalam mengatur waktu sehingga siswa sering datang terlambat kesekolah. Adapun hasil penelitian yang didapat disekolah:

1. Strategi guru bimbingan dan konseling dalam memberikan layanan kepada siswa yang tidak disiplin di SMP Negeri 17 Banjarmasin. Sebagai guru BK tentu saja memiliki banyak sekali tanggung jawab didalamnya, setiap siswa memiliki karakter dan potensi diri yang berbedabeda sehingga cara penanganannya pun juga berbeda, hal ini menjadikan guru bk harus menjadi inovatif dan kreatif. Guru BK memberikan konseling kepada peserta didik yang membutuhkan, mendengarkan segala keluhan dan menolong mereka untuk meyakinkan diri mereka bahwa setiap masalah dan persolaan yang menimpa dirinya adalah bagian kehidupan yang harus dijalani, berbica mengenai konseling adalah keahlian mutlak yang harus dimiliki guru BK untuk menunjukkan bahwa dirinya profesional, bukan sekedar sebutan namun melalui konseling peserta didik dapat menemukan dirinya, beradaptasi dengan lingkungan dan bisa membantu dalam merencanakan masa depan peserta didik. 
Yohana, Gusti Irhamni, Ainun Heiriyah

Jurnal Bimbingan dan Konseling Ar-Rahman

Volume 5, Nomor 2, Tahun 2019

e-ISSN 2477-6300

Layanan Konseling Individual layanan ini diberikan oleh guru bimbingan dan konseling ketika siswa tersebut sudah mengalami masalah. Layanan konseling individual yang bersifat sangat pribadi yang mana guru BK sebagai konselor hanya berdua dengan siswa sebagai konseli ini nampaknya cukup memberikan rasa percaya siswa yang lebih kepada guru BK, sehingga didapati oleh guru BK siswa lebih leluasa dan terbuka saat menceritakan apapun masalah yang sedang dihadapinya.

Dalam prosesnya memberikan layanan konseling individual guru bimbingan dan konseling melaksanakannya pada dua minggu sekali, layanan yang diberikan biasanya 40 menit jika belum bisa menemukan pemecahan masalahnya siswa diberikan lagi layanan konseling selanjutnya hingga siswa tersebut bisa memecahkan masalahnya sendiri dan berubah dengan caranya sendiri dengan arahan yang baik dari guru bimbingan dan konseling. Pada kasus ketidak disiplinan ini guru bimbingan dan konseling pada saat memberikan layanan juga memasukkan teknik modelling yaitu salah satu teknik dalam pendekatan behavioristik dengan guru bimbingan dan konseling sendiri yang berperan menjadi model disiplin terlebih dahulu, dan diharapkan siswa yang kurang disiplin bisa menjadikan guru bimbingan dan konseling sebagai pigur yang bertanggung jawab dan disiplin terhadap aturan-aturan yang ada disekolah.

2. Apa saja penyebab siswa menjadi tidak disiplin di SMP Negeri 17 Banjarmasin. Masa remaja adalah masa usia-usia yang sering menghadapi berbagai keadaan, yang mana pada titik usia ini akan menjadi penentu seperti apa individu tersebut di masa yang akan datang. Berbicara mengenai remaja disekolah masih ada peserta didik yang tidak menaati peraturan-peraturan disekolah. Pada SMP Negeri 17 Banjarmasin ditemui masih ada siswa dan siswi yang melanggar peraturan-peraturan yang ada disekolah, salah satunya yakni siswa yang tidak disiplin sering datang terlambat kesekolah, padahal aturan tersebut sudah ada dan juga sudah diketahui oleh siswa-siswi tetapi masih saja ada yang melanggar. Sesuai dengan observasi yang peneliti lakukan peneliti menemukan siswa yang sering datang terlambat kesekolah, keterlambatan ini pun tanpa alasan yang logis, siswa-siswa tersebut saat di wawancarai mengaku penyebab keterlambatannya dikarenakan malam bergadang, sehingga berakibat pagi bangun kesiangan, dan salah satu siswa tersebut mengaku dalam bergadang dia asik bermain game, untuk siswa yang sering datang terlambat mereka mengaku bahwa yang mengakibatkan ketidak disiplinan itu dari dirinya sendiri bukan dari faktor luar.

Kendala-kendala yang dihadapi guru Bimbingan dan Konseling adalah siswa sering tidak mau terbuka tentang dirinya terlambat datang kesekolah, hal itu dikarenakan mereka malu dan takut dicap sebagai orang yang bermasalah ketika berurusan dengan bimbingan dan konseling. Menurut pengakuan responden penghambat guru bimbingan dan konseling biasanya, dari guru karena ada beberapa guru mata pelajaran yang kurang tau guru BK itu apa keahliannya ada juga yang meremehkan cuman tidak langsung. Kemudian menurut ibu Rida kendala yang dihadapi guru bimbingan dan konseling dalam memberikan pengajaran ini mungkin untuk waktu jam pengajaran, karna biasanya guru bimbingan dan konseling disekolah ini hanya diberikan waktu satu jam pelajaran dan juga mungkin guru bimbingan dan konseling tidak bisa mengawasi full 24 jam siswasiswi nya, dan menurut kepala sekolah kendala yang dihadapi guru BK adalah sarana dan prasarana yang belum memadai.

\section{PENUTUP}

Strategi yang dipakai guru Bimbingan dan Konseling mengatasi siswa yang kurang disiplin sering datang terlambat kesekolah adalah konseling individual dengan teknik modelling. layanan ini dianggap berhasil dalam mengurangi ketidak disiplinan siswa. Penyebab yang membuat siswa sering datang terlambat kesekolah merupakan faktor dari dirinya sendiri, bukan dari faktor luar. Kendala yang dihadapi guru Bimbingan dan Konseling adalah, siswa yang sering terlambat ini menganggap dirinya hebat dan kebal terhadap peraturan-peraturan yang ada disekolah, dan kendala utama dalam memberikan layanan konseling individual ini adalah sarana dan prasarana yang belum memadai. Kemudian guru Bimbingan dan Konseling dalam memberikan pengajaran juga mendapat kendala diwaktu jam pengajaran, karna disekolah guru Bimbingan dan Konseling ini hanya diberikan waktu satu jam pelajaran setiap masuk kelas dan juga guru Bimbingan dan Konseling tidak bisa mengawasi full 24 peserta didik.

Berdasarkan hasil penggalian data hasil wawancara bersama kepala sekolah, mengatakan adanya guru BK dalam sebuah sekolah sangatlah 
Yohana, Gusti Irhamni, Ainun Heiriyah

Jurnal Bimbingan dan Konseling Ar-Rahman

Volume 5, Nomor 2, Tahun 2019

e-ISSN 2477-6300

penting, karena guru BK dapat berkontribusi dengan pihak-pihak yang ada disekolah untuk dapat memahami siswa-siswi disekolah. Guru BK sangat berpengaruh terhadap kedisiplinan peserta didik, tetapi ada saja problem guru BK disekolah ini yakni sarana dan prasarana yang kurang memadai, karena tidak adanya ruangan khusus untuk layanan konseling individual padahal layanan ini mengurangi ketidak disiplinan peserta didik, dan wali kelas mengatakan guru BK memberikan pengajaran juga seperti guru mata pelajaran, dan mebimbing peserta didik, materi yang disampaikan guru BK menurut ibu Rida mungkin lebih ke etika bagaimana si siswa bersikap disekolah, dan diluar sekolah, materi-materi atau caracara bersikap di lingkungan sosialnya. Dengan adanya guru BK sangat membantu sekali untuk sekolah, karena guru BK mengajarkan tingkah laku yang baik, dan segala macam yang berkaitan dengan si siswa.

Adapun faktor pendukung dan penghabat guru BK menurut ibu Rida adalah faktor pendukungnya guru-guru mata pelajaran yang ikut serta sedikit banyaknya juga memberikan pengajaran tentang etika atau tingkah laku kesiswa, serta faktor penghambat guru BK memberikan pengajaran ini mungkin kewaktu jam pengajaran karna biasanya guru BK ini hanya diberikan waktu satu jam pelajaran dan juga mungkin guru BK tidak bisa mengawasi full 24 peserta didik. Untuk siswa yang sering datang terlambat guru BK biasanya memberikan motivasi kepada peserta didik yang terlambat agar semangat dan disiplin. Menurut pengakuan ibu Rida Guru BK sering melaksanakan layanan konseling individual kepada siswa yang sering datang terlambat, layanan nya pun sangat mengurangi, karenakan konseling individual ini secara bertatap muka jadi si anak lebih leluasa untuk menyampaikan isi hatinya, pikirannya, dan bisa berbicara dari hati kehati dengan guru BK, guru BK pun bisa lebih mengerti kondisi si anak jika konseling individual. Berdasarkan hasil penelitian dapat diketahui bahwa layanan konseling individual yang diberikan guru Bimbingan dan Konseling disekolah kepada siswa yang sering datang terlambat kesekolah dapat perlahan-lahan menaati aturan yang berlaku.

Bagi Guru Bimbingan dan Konseling layanan konseling individual yang diberikan mampu memberikan penurunan terhadap kedisiplinan kepada siswa yang tidak disiplin sering datang terlambat kesekolah. Bagi Siswa-siswi SMP Negeri 17 Banjarmasin, diharapkan menurunkan perilaku yang tidak disiplin dalam menaati peraturan-peraturan yang ada disekolah. Bagi Peneliti Selanjutnya diharapkan untuk lebih mendalami strategi yang dipakai oleh Guru Bimbingan dan Konseling dalam memberikan layanan-layanan yang berhasil disekolah. Dikarenakan peneliti hanya melakukan penelitian pada tahap salah satu strategi layanan saja yang sering digunakan yakni konseling individual, dan untuk umum kedisiplinan sangatlah penting bagi kehidupan, maka mulai lah dari diri sendiri terlebih dulu sebelum merenapkannya keorang lain.

\section{REFERENSI}

Fiana, F.J., Daharnis, \& Mursyid, R. (2013). Disiplin Siswa di Sekolah dan Implikasinya dalam Pelayanan Bimbingan dan Konseling. Konselor, 2(3), 30-31.

Husni, M. (2017). Layanan Konseling Individual Remaja Pendekatan Behaviorisme. Al-Ibrah, 2(2), 57-59.

Ilahi, R., Syahniar, \& Ibrahim, I. (2013). Faktor yang Mempengaruhi Pelanggaran Disiplin Siswa dan Implikasinya Terhadap Layanan Bimbingan \& Konseling. Konselor, 2(2), 2021.

Noviaty, D., Yuliansyah, M, \& Fauzi, Z. (2018). Strategi Guru Bimbingan dan Konseling dalam Meningkatkan Kedisiplinan Siswa di MAN 1 Banjarmasin. Jurnal Mahasiswa BK An-Nur, 4(3), 7-10.

Suhardi, D. (2017). Nilai Karakter Refleksi Untuk Pendidikan. Depok: PT RajaGrafindo Persada.

Sugiyono. (2016). Metode Penelitian Pendidikan (Pendekatan Kuantitatif, Kualitatif, dan $R \& D)$. Bandung: Alfabeta.

Sulaiman, B. Z. (2013). Hubungan Persepsi Kesesakan (Crowding) dan Kematangan Emosi Dengan Disiplin Berlalu Lintas Pada Remaja Akhir SMAN 1, SMAN 3, dan SMAN 4 Kota Malang. Skripsi. Malang: Fakultas Psikologi Universitas Negeri Malang.

Yusuf, S. L. N., \& Nurihsan, J. (2016). Landasan Bimbingan \& Konseling. Bandung: PT Remaja Rosdakarya Offset. 